\title{
Cinema documentário como forma de pensamento
}

\author{
Documentary cinema as a way of thinking
}

\author{
Dulcília Schroeder Buitoni - ESPM | São Paulo | SP | Brasil | E-mail: \\ dbuitoni@uol.com.br
}

Resumo: Com o objetivo de descrever e analisar formatos inovadores de filmes documentários que contribuíram e contribuem para trazer elementos de educação visual e até de transformações cognitivas, este artigo discutiu relações entre a estética documental e o real e trabalhou com conceitos como fotografiadocumento e fotografia-expressão (André Rouillé), imagem-câmera (Fernão Ramos) e imagem complexa (Josep M. Català). Sob uma mirada fenomenológica, a análise das obras cinematográficas selecionadas - Um homem com uma câmera (Dziga Vertov, 1929), Valsa com Bashir (Ari Folman, 2008) e Sementes do nosso quintal (Fernanda Figueiredo, 2012) - apontou transgressões e novas formas de registrar e editar imagens. Os três filmes têm uma dimensão experimental; produziram imagens-expressão e imagens complexas, o que significa que incluíram subjetividade e arte em produções visuais que estimulam processos educadores e reflexivos e propiciam elementos para criação de novas formas documentais. Propõem exercícios de pensamento e formas de produção; além de pensar as imagens, pensar com imagens.

Palavras-chave: Documentário. Formas do real. Imagens pensativas.

Abstract: With the purpose of describing and analyzing innovative formats of documentary films that contributed and contributed to bring elements of visual education and even cognitive transformations, this article discussed relations between documentary and aesthetics of real and worked with concepts such as photography-document and photography-expression (André Rouillé), imagecamera (Fernão Ramos) and complex image (Josep M. Català). Under a phenomenological perspective, the analysis of selected cinematographic works A man with a camera (Dziga Vertov, 1929), Waltz with Bashir (Ari Folman, 2008) and Sementes do nosso quintal (Seeds from our backyard, Fernanda Figueiredo, 2012) - pointed to transgressions and new forms to record and edit images. The three films have an experimental dimension; produced images-expression and complex images, which means that they included subjectivity and art in visual productions that stimulate educative and reflective processes and provide elements for the creation of new documentary forms. They propose thought exercises and forms of production; besides thinking the images, think with images.

Keywords: Documentary. Forms of real. Thoughtful images.

DOI: http://dx.doi.org/10.22484/2177-5788.2018v44n1p29-52

Recebido em maio 2018. $\quad$ Aprovado em maio de 2018.

REU, Sorocaba, SP, v. 44, n. 1, p. $29-52$, jun. 2018 


\section{Uma perspectiva fenomenológica}

A fenomenologia aponta caminhos para perceber o interior das imagens, na tentativa de desvendar a complexidade cognoscitiva de nossas percepções visuais. Se as imagens cinematográficas forem o objeto, aumenta a possibilidade de aplicação de uma perspectiva fenomenológica e, no caso da imagem documental, a mirada fenomenológica parece ainda mais necessária. Quase sempre os textos costumam recorrer às noções de rastro e índice, embora muitos autores façam ressalvas à explicação inicial. O índice continua a ser um elemento importante para a reflexão sobre a imagem de matriz fotográfica e será brevemente trabalhado aqui. Porém, nosso principal intuito se concentrará na observação de como alguns documentários cinematográficos produziram imagens dentro de uma concepção inovadora.

O cinema sempre teve uma dimensão formadora. Começou registrando cenas do real e depois assumiu discursos ficcionais, construindo mundos. Edgar Morin (1962), no seu L'Esprit du Temps (traduzido no Brasil como Cultura de Massas no Século XX), apontava o cinema como elemento configurador do século XX. A estética do filme documental inclui ainda com mais força o aspecto formador. Ao focalizar o cinema documentário, interessa-nos a função formativa, geralmente exposta em seu conteúdo e principalmente discutir como a construção de novos olhares se relaciona com formas de pensamento e conhecimento. Nesse sentido, examinar a fenomenologia de imagens documentais singulares amplifica seu caráter de instrumento de pensamento criador.

No caminho desta investigação, foi cometida a temeridade de reunir documentários muito distintos entre si. Assim, serão discutidos Um homem com uma câmera (1929), representante maior do Cine-olho, do russo Dziga Vertov, e dois filmes mais recentes: Valsa com Bashir (2008), do israelense Ari Folman, e o brasileiro Sementes do nosso quintal (2012), de Fernanda Heinz Figueiredo. Os temas também são diversos: o cotidiano russo pós- 
Revolução, as memórias de um soldado israelense em ação no Líbano e a vivência de crianças numa escola de educação infantil de pedagogia inovadora, no Brasil. Os três documentários se destacam por suas maneiras de representar o real. Para refletir sobre a feitura das imagens desses documentários, serão usados autores como André Rouillé, Dziga Vertov, Margarita Ledo, Philippe Dubois, Fernão Pessoa Ramos e Josep M. Català e conceitos como fotografia-documento e fotografia-expressão, imagemvídeo, imagem-câmera e imagem complexa.

As coordenadas de tempo e espaço estão vivendo em constante mutação. Como pensar a forma documentário em relação à multiplicidade de tempos e espaços? Josep M. Català (2017, p. 152-153), professor da Universidad Autònoma de Barcelona e criador de um Master em Documental Criativo, assinala que nossa era é multimidiática, não só porque os diversos meios se acumulam, mas também porque eles interagem constantemente entre si e em diversos níveis. Ele ressalva que as outras épocas também eram multimidiáticas; a diferença é que antes não existiam os contêineres que agora aglutinam diversos meios. Os mais importantes são o computador e o televisor, que também tendem a confluir em um só dispositivo. Assim, chegamos à tela, que se iniciou no ocidente com a invenção do quadro. Para Català (2017), o modo quadro, como antes o modo teatro e, depois, o modo cinema, tendia a estabelecer uma confluência entre a realidade, a representação e a mente. Havia esse espaço bidimensional que se prolongava ilusoriamente, por um lado em direção à realidade e por outro em direção à mente. Ao incorporar o movimento, a imagem cinematográfica aumentou e intensificou essa confluência; essa imagem que aparece na tela só existe em estado fluido quando tem um observador. Hoje, a mão no mouse ou o dedo que toca a tela touch dá condições de se relacionar de novo com a imagem, como o desenhista, o pintor ou o escultor - e diminuíram a distância entre sujeito e objeto. Agora há uma operatividade real através das interfaces, as quais são o equivalente funcional da imagem fluida que promove o movimento-tempo. Català 
(2005) nos diz que não se trata de renunciar à reflexão em favor da simples manipulação, mas que o processo de reflexão se reforça mediante o contato direto com o objeto examinado. Já não estamos, pois, diante de imagens para contemplar; porém, em cada imagem, confluem primeiro o tato e a visão, e com a multimídia, todos os sentidos, para produzir estados reflexivos. No entanto, a consideração dessa possibilidade, propiciada pela tecnologia, de interagir diretamente com a imagem, não é necessária para o raciocínio que desenvolvemos neste texto. Aqui, o foco é a produção de imagens cinematográficas que trazem inovação e que provocam conseqüências educativas.

\section{Documentário: real, realidades}

Como o cinema documentário produz o real? Philippe Dubois, belga radicado na França e professor de cinema e audiovisual na Universidade Sorbonne Nouvelle (Paris 3), importante teórico da imagem, é autor de 0 ato fotográfico, livro que discute a fenomenologia da fotografia. Ele resume as diversas posições adotadas sobre essa imagem técnica: alguns consideram a fotografia como um autêntico "espelho do real"; outros, "transformação do real"; e outros, "traço de um real". Ao se constituir a partir de uma conexão física com o seu referente, a foto é um traço que atesta a existência daquele objeto e/ou cena naquele momento. Ela não explica, não interpreta; simplesmente mostra. Depois, muitas operações irão modificar a imagem capturada: a antiga revelação, a edição, a publicação, o compartilhamento. Dubois explica: "em suma não é uma aposta menor dessa lógica do índice colocar radicalmente a imagem fotográfica como impensável fora do próprio ato que a faz ser" (DUBOIS, 1994, p. 79). Por isso, o título do seu livro, O ato fotográfico. O índice só existe naquela fração de segundo em que a impressão luminosa é registrada. Se pensarmos na dimensão pragmática da fotografia, que se concentra no índice, poderíamos justificar o argumento jornalístico de 
vinculação com a realidade. $E$, por extensão, o cinema documentário também teria como fundamento ser "traço de um real".

No entanto, muitos autores criticam o índice como justificativa de relação com o real. Margarita Ledo (1998), professora da Universidad de Santiago de Compostela, pondera que percebemos a fotografia como analogon e ao mesmo tempo como codificação do real. Por isso, "que a foto se anuncie como imagem que constata, não quer dizer que se reduza a constatar, a dar fé, ou a preservar a aparência do que já desapareceu, como uma simples extensão da nossa memória" (LEDO, 1998, p. 37). O teórico e historiador francês André Rouillé considera que a fotografia, "mesmo a documental, não representa automaticamente o real; e não toma o lugar de algo externo. Como o discurso e as outras imagens, o dogma de ser rastro mascara o que a fotografia, com seus próprios meios, faz ser: construída do início ao fim, ela fabrica e produz os mundos" (ROUILLÉ, 2009 , p. 18). Para ele, a fotografia não é um documento (aliás, como qualquer outra imagem), mas somente está provida de um valor documental, variável segundo as circunstâncias. Trata da fotografiadocumento como fotografia simplesmente utilitária, não para imobilizá-la em uma essência, mas para analisar seus funcionamentos e evolução. Esse propósito também norteia esta reflexão - examinar como documentários construíram novas formas de ver e pensar o mundo e como contribuíram e contribuem para a expansão do olhar e do pensamento. O caráter indicial continua a ser um poderoso argumento para o senso comum; está no horizonte da produção de filmes documentários - algumas obras inclusive utilizam a questão do real como reflexão metalinguística -, mas não é a preocupação central deste trabalho, que se concentra em dimensões fenomenológicas.

Rouillé (2009) criou o conceito de fotografia-expressão para refletir sobre como a fotografia foi adquirindo características expressivas tornando possível sua qualificação como arte. A fotografia-expressão não assegura 
relação direta - sequer reduzida ou transparente - com as coisas. Não coloca, face a face, real e imagem em uma relação de aderência:

Entre o real e a imagem sempre se interpõem uma serie infinita de outras imagens, invisíveis porém operantes, que se constituem em ordem visual, em prescrições icônicas, em esquemas estéticos. Mesmo quando está com contato com as coisas, o fotógrafo não está mais próximo do real do que o pintor trabalhando diante de sua tela. (ROUILLÉ, 2009, p. 19).

A passagem do documento à expressão se traduziu em profundas mudanças nos procedimentos e nas produções fotográficas, bem como no critério de verdade. Rouillé mostra que enquanto a fotografia-documento se apoia na crença de ser uma impressão direta, a fotografia-expressão assume seu caráter indireto: "Do documento à expressão, consolidam-se os principais rejeitados da ideologia documental: a imagem com suas formas e sua escrita; o autor com sua subjetividade; e o Outro, enquanto dialogicamente implicado no processo fotográfico" (ROUILLÉ, 2009, p. 19).

A transição que se operou do documento à expressão é descrita no livro de Rouillé que, ao trabalhar com as relações entre fotografia e arte, explorou dois territórios que considera como distintos: a arte dos fotógrafos e a fotografia dos artistas. O cinema documentário também pode ser analisado enquanto imagem-documento que pode adquirir facetas de imagem-expressão. O começo do cinema foi documental, indicial. Rapidamente, o cinema foi adquirindo contornos da literatura e do teatro discursos de ficção. O cineasta russo Dziga Vertov defendia que o cinema desenvolvesse a sua própria linguagem. Não poderia ser adaptação de obras literárias, nem criar cenas teatrais: "montar significa organizar os pedaços filmados (as imagens) num filme, 'escrever' o filme por meio das imagens filmadas, e não, escolher pedaços de filme para fazer 'cenas' (desvio teatral) ou pedaços filmados para construir legendas (desvio literário)" (VERTOV, 1983a, p. 261). Na verdade, para ele, a busca da linguagem cinematográfica como estudo do movimento significava a 
intensificação do discurso visual produzida por filmagens e montagens que podemos classificar como uma estética de documentário.

As ideias de Vertov ecoam de alguma maneira em um texto que se tornou clássico - O antidocumentário provisoriamente -, do fotógrafo, cineasta e multiartista brasileiro Arthur Omar, um dos primeiros a fazer vídeoarte. Saiu primeiramente em 1972 no Caderno Comunicação do Jornal do Brasil e depois foi publicado em 1978, na revista Vozes no 6. Omar acentua que uma forma monolítica se impôs na história do cinema: o filme narrativo de ficção formou um leito onde iria correr todo o resto. A forma documentário é inteiramente tributária dessa vertente principal da história do cinema.

\begin{abstract}
A partir da invenção da câmera de filmar, o cinema poderia ter sido utilizado para outros fins, técnicos e científicos, mas os grandes investimentos necessários à sua prática fixaram sua evolução dentro de uma única matriz, que é a de servir como um espetáculo público, recuperando e expandindo o teatro e o romance. Toda a linguagem do cinema se desenvolveu dentro dessa matriz, sem qualquer outra alternativa, desde os filmes didáticos até os publicitários, passando pela dita vanguarda cinematográfica, que nada mais fez que funcionar como margem necessária que delimita esse campo irresistível (OMAR, 1978, p. 405).
\end{abstract}

Assim, não existe o filme documentário como linguagem autônoma; o documentário tal como existe hoje é um subproduto da ficção narrativa, sem conter em si qualquer aparato formal e estético, que lhe permita cumprir com independência seu hipotético programa mínimo: documentar. Omar continua o raciocínio, afirmando que as conquistas formais do filme narrativo de ficção foram sendo incorporadas aleatoriamente ao documentário, como procedimentos que vêm de fora; todas as tentativas de dar ao documentário uma independência foram infrutíferas diante da presença avassaladora do filme de ficção. Omar resume: na medida em que o cinema narrativo de ficção determina o cinema documentário, poderia se dizer que o que o cinema de fiç̧ão trabalha como sendo real (mesmo que fosse um real fictício) é o mesmo que o documentário representa como sendo ficção (mesmo que seja uma ficção real). "A mística é a mesma: há REU, Sorocaba, SP, v. 44, n. 1, p. $29-52$, jun. 2018 
um continuum fotografável que pode ser dado à visão, uma verdade que se apreende imediatamente" (OMAR, 1978, p. 405).

Para Omar (1978), o cinema de ficção aperfeiçoou uma série de dispositivos estéticos, visando a tornar mais real o que ele queria apresentar como realidade; o documentário absorveu esses dispositivos e acaba apresentando a realidade documental como se fosse ficção. Por exemplo, muitos documentários buscam personagens que possibilitem uma narrativa: ao mostrar uma realidade no campo ou na cidade, as imagens se articulam em torno de um personagem que acaba adquirindo tons heroicos, dramáticos - enfim, uma idealização. É difícil encadear cenas sem cair na tentação de contar uma história. O cineasta criticava a atitude de conservação e preservação praticada pelos filmes documentários daquela época, sobre cenas da cultura brasileira. Nesse período, havia uma lei que exigia um complemento nacional às exibições de filmes estrangeiros, o que provocava uma grande produção de documentários "culturais" de baixa qualidade. Em contraposição, Arthur Omar realizou Congo (1972), que se iniciava com uma frase de caráter programático: "um filme em branco". 0 espectador verá uma série de letreiros, às vezes telas completamente brancas e o som do que seria uma congada. Há pouquíssimas imagens cinematográficas. Ele lê e ouve o som e tem que imaginar o que seria essa manifestação folclórica. Contra a mesmice da maioria dos documentários, Omar diz que Congo não deveria ser analisado como um modelo contraposto a outro modelo, mas como um ponto fora do perímetro.

\section{Rússia, Israel e Brasil: formas no tempo e no espaço}

Dziga Vertov, lançador do movimento Cine-olho (Kino-Glaz), buscava, nos anos 1920, uma estética própria do cinema sem que as imagens se submetessem à linguagem da literatura e do teatro. Em seus escritos/manifestos, Vertov acentuava a dimensão formadora e educativa da sua proposta de linguagem cinematográfica: "nós introduzimos a alegria criadora em cada trabalho mecânico, nós aproximamos os homens das 
máquinas, nós educamos os novos homens" (VERTOV, 1983c, p. 249). Para ele, a câmera deveria funcionar como uma extensão do olho, daí o nome de cine-olho: as imagens seriam montadas pela proximidade das formas e não obedecendo a uma cronologia e história prévia. Realmente a montagem era um dos pontos-chave da produção de Vertov, que inclusive conseguiu operar uma série de inovações. Filmado em Moscou, Kiev, Yalta e Odessa, seu documentário "Um homem com uma câmera", reúne uma série de cenas cotidianas - principalmente de cidades - sem que haja narrativa; a montagem, bastante experimental, obedece a semelhanças de forma e função. Seguindo essa linha, Vertov conseguiu realizar várias de suas propostas que apareceram em seus textos e manifestos:

\footnotetext{
O principal, o essencial

É a cine-sensação do mundo. (VERTOV, 1983d, p. 253).

"Cine-olho" como cine-análise

"Cine-olho" como "teoria dos intervalos"

"Cine-olho" como teoria da relatividade na tela, etc... (VERTOV, 1983b, p. 261).

Montar significa organizar os pedaços filmados (as imagens) num filme, "escrever" o filme por meio das imagens filmadas, e não, escolher pedaços de filme para fazer "cenas" (desvio teatral) ou pedaços filmados para construir legendas (desvio literário) (VERTOV, 1983a, p. 263).
}

A coreografia de gestos humanos é associada ao movimento de engrenagens: rodas de carros e carroças, locomotivas, minas, trotar de cavalos, recém-nascidos, parto, enterro, casamento, bondes, aviões, represas, cuidados corporais, produtos sendo embalados em esteiras de fábricas, aparelhos de ginástica, banhistas na praia, muitos cruzamentos de tráfego e muita movimentação de pedestres nas ruas. Transições lentas, cortes abruptos, telas duplicadas, aceleração, lentidão. Há momentos de metalinguagem quando a montadora separa um fotograma, exibido em uma cena estática, que logo ganha movimento e nos lembra uma sequência já vista. Vertov é contra a encenação e a narrativa, mas faz pequenas concessões ao mostrar um casamento seguido de um divórcio ou alternar parto e enterro. $O$ filme também foi montado para exibir momentos de um 
dia: começa pela manhã, o despertar de uma jovem em sua cama - e ela tem um pesadelo -, e termina com o anoitecer.

Vertov considera seu trabalho como cine-pesquisa, cuja leveza da montagem permite introduzir quaisquer motivos políticos, econômicos ou outros: "consequentemente, doravante não serão mais necessários dramas psicológicos ou policiais no cinema, doravante não haverá mais necessidade de montagens teatrais fotografadas sobre película" (VERTOV, 1983d, p. 259). Todo filme do "cine-olho" é montagem durante todo o processo de sua fabricação. Primeiramente, há o inventário de todos os dados documentais (manuscritos, objetos, trechos filmados, fotografias, recortes de jornal, livros etc.) que tenham alguma relação direta ou não com o tema tratado. A montagem final envolverá:

Associação (adição, subtração, multiplicação, divisão e colocação entre parênteses) dos trechos filmados do mesmo tipo. Permuta incessante desses pedaços-imagens até que todos sejam colocados numa ordem rítmica em que os encadeamentos de sentidos coincidam com os encadeamentos visuais. Como resultado final de todas essas junções, deslocamentos, cortes, obtemos uma espécie de equação visual, uma espécie de fórmula visual (VERTOV, 1983a, p. 264).

Inicialmente silencioso, Um homem com uma câmera foi construído para ser visto e também ouvido: uma trilha sonora foi composta sob orientação de Vertov e era executada por um conjunto de músicos. Atualmente, temos acesso a uma cópia restaurada pela Eastman; as versões que vemos hoje são acompanhadas de gravações feitas modernamente dessa trilha. No início do seu filme, Vertov adverte:

Atenção espectadores:

Este filme é um experimento na comunicação cinemática de eventos reais Sem ajuda de legendas explicativas

Sem ajuda de cenário

Sem ajuda de teatro 
Este trabalho experimental tem como objetivo criar uma linguagem internacional de cinema baseada na separação absoluta da linguagem do teatro e da literatura.

Realmente, o cineasta conseguiu produzir uma obra experimental, inventiva, transgressora, que ainda hoje apresenta elementos inovadores e serve de inspiração para estudantes de cinema. O propósito de educação do olhar está em cada sequência de Um homem com uma câmera.

A experimentação visual empreendida por Vertov permite até uma extrapolação comparativa com a imagem videográfica. Philippe Dubois diferencia as imagens cinematográficas das imagens videográficas, em seu livro Cinema, vídeo, Godard (2004). O cinema adota a perspectiva monocular: considera-se a centralidade visual, para onde devem convergir os olhares. A imagem cinematográfica é construída também como se fosse dirigida a um único espectador. Por isso, trabalha muito com a profundidade de campo, indo numa escala de planos (primeiro plano, plano médio, plano geral, etc. ...), que ajuda a compor diferentes graus de densidade dramática. Há uma homogeneidade estrutural do espaço. Vertov utiliza a perspectiva monocular, centralizadora do olhar e uma grande variedade de planos. Porém, trabalha com superposições com divisão em duas ou mais telas já rompendo com o padrão cinematográfico dominante. Em relação ao vídeo, Dubois (2004) sugere que pensemos o vídeo como um estado e não como um produto. Para ele, a imagem-vídeo é o lugar da fragmentação, da edição, do descentramento, do desequilíbrio, da heterogeneidade estrutural do espaço. A imagem-vídeo pode ter incrustações, letreiros, personagens que entram e saem de repente. Nesse sentido, Vertov conseguiu realizar um tipo de edição que se assemelha à edição de vídeo contemporânea, mesmo trabalhando só com moviola e película.

Valsa com Bashir é um filme de animação que pode ser classificado como documentário. Alguns paradoxos se apresentam: como um filme inteiramente desenhado pode ser considerado como documentário? A 
matriz fotográfica não está presente na quase totalidade de suas imagens, o que prejudicaria a qualificação do caráter indicial. O filme, com roteiro e direção do israelense Ari Folman, é uma narrativa em primeira pessoa - e ele é o próprio personagem que faz um percurso para reconstruir memórias de situação de guerra, memórias das quais não conseguia se lembrar. Espécie de viagem interior em que procura alguns companheiros que estavam com ele no mesmo batalhão do exército, a animação trabalha com desenhos baseados em fotografias das pessoas reais. Ele mesmo, Ari Folman, aparece no início do filme, mais velho, e quando surgem as lembranças, vemos sua figura como jovem soldado do exército de Israel. Poderia ser considerado como um formato de docudrama que reencenasse sua busca pelos colegas, cada um vivendo histórias muito diferentes na atualidade. A animação vai apresentando alguns encontros mais recentes, entremeados por flashbacks de deslocamentos, embates, mortes, que pouco a pouco vão aclarando sua memória até trazerem de volta as vivências esquecidas. O filme se baseia nas experiências-limite que 0 cineasta viveu. Ari Folman participara da incursão de tropas israelenses no Líbano, quando acabou sendo testemunha presencial do massacre de Sabra e Chatila, em 1982. O presidente eleito Bashir Gemayel fora morto em um atentado com explosivos na sede central das Forças Libanesas em Beirute; em represália, a Falange Libanesa fez um massacre em acampamento de refugiados palestinos e as forças israelenses presentes na região foram indiretamente responsáveis por não evitar as matanças.

A inovação de Valsa com Bashir não está em romper com esquemas narrativos. A grande diferença está na produção de uma obra que pode ser considerada documentário com uma visualidade que à primeira vista não parece adequada para se fazer um documentário. Sua narrativa afasta-se do convencional principalmente pelo não uso da imagem de matriz fotográfica. O estilo do seu desenho lembra graphic novels, a trilha sonora é contemporânea. Ele não se contrapõe ao uso da narrativa, como fez Vertov; apenas mudou a forma de representação. Ao invés de sequências 
fotográficas, contou uma história com animação de desenhos. Apenas no final, quando os espectadores estão completamente envolvidos pelo efeito de realidade, há o corte para a documentação filmada dos corpos de homens, mulheres e crianças mortos no acampamento palestino. Os personagens desenhados entram no acampamento e então veem as imagens de matriz fotográfica, um pouco desbotadas. Toda a narrativa desenhada termina com a visão do "real" fotográfico. O desenho transita para a fotografia. Seria uma forma de comprovação?

O terceiro exemplo é o documentário longa-metragem Sementes do nosso quintal, de Fernanda Heinz Figueiredo, lançado em outubro de 2012, que retrata o cotidiano de uma escola infantil, em São Paulo, a Te-Arte, criada por Therezita Pagani. Selecionado para a 36a Mostra Internacional de Cinema de São Paulo (2012), recebeu o prêmio do público de melhor documentário brasileiro; também foi premiado no Festival du Film D'Éducation (2013, França), promovido pela Association Nationale Festival du Film d'Éducation.

Este filme não visava propostas estéticas tão inovadoras quanto Um homem com uma câmera e Valsa com Bashir. Seu objetivo era mostrar, de um modo bastante espontâneo, vivências de uma pedagogia infantil, essa sim inovadora. Não é um documentário convencional, que intercala depoimentos de especialistas com cenas em que as crianças brincam, quase sempre em um espaço aberto, semelhante a um quintal de antigamente. A diretora Fernanda Figueiredo, ex-aluna da Te-Arte, optou por uma junção de planos-sequência que refletem a pedagogia em processo. Segundo a sinopse, "o pensamento-em-ação de sua idealizadora nos revela o potencial estruturante da educação verdadeira, firme e sensível". Em alguns momentos, a voz em off de Therezita pontua gestos e cenas ou discorre sobre algum "acontecido" no ambiente educativo. A diretora montou o documentário a partir de material gravado durante 4 anos. Therezita, com 81 anos na época do lançamento do filme, e ainda hoje em franca atividade, 
"estabelece um diálogo simples, verdadeiro e ancestral com as crianças, famílias e adultos que estão a sua volta". Ela criou seu trabalho a partir de sua experiência e corpos vividos.

As cenas vão se sucedendo, sem obedecer a um roteiro fechado e fortemente estruturado. Os cinegrafistas profissionais tornaram-se mais alguns "adultos" que trabalhavam na escola e as crianças encaravam o convívio com muita naturalidade. Ninguém posava; as câmeras faziam parte da movimentação de todo dia, que facilitou a grande maioria de registros espontâneos. Assim, o ritmo das filmagens acompanhava o ritmo das brincadeiras infantis. A gravação com microfone "boom" permitiu a captação de diálogos e falas de muita naturalidade. Junto à sinopse, o comentário: "aos poucos, vemos também surgir como personagem do documentário o próprio espaço escolar, um organismo vivo, orgânico e poético em constante mutação, reflexo das mudanças de estação do ano, do ciclo de festas populares e das atividades que giram em torno do brincar espontâneo, onde as crianças e adultos se conhecem, interagem e crescem".

A feitura do filme também obedeceu a ritmos vitais; sua pré-produção e pesquisa começou em 2007, quando a primeira filha da realizadora iniciou sua adaptação na Te-Arte. As gravações tiveram início no primeiro semestre deste ano. Com uma equipe afinada para atuar por tanto tempo e com tanta intensidade em um ambiente tão sensível quanto uma escola infantil, houve gravações em 2008, 2009 e principalmente em 2010 quando, após a viabilização financeira do projeto, foram realizadas mais de 30 diárias. As mais de 450 horas de filmagens foram condensadas no longa de 118 minutos. 


\begin{abstract}
Aos poucos, o filme nos coloca ao lado de alguns personagens com quem reciclamos o barro, mexemos na lama, encaramos um ganso solto, observamos e nos esquivamos da experiência da morte, brincamos, cantamos, dançamos, experimentamos sabores, choramos e vivenciamos sentimentos, desafios, questionamentos e os ciclos da cultura popular brasileira. Nunca seguindo uma lógica rígida, mas trazendo nuances do subjetivo e do imaginário, assim como é a infância (Sinopse e material de suporte).
\end{abstract}

Sementes do nosso quintal resulta de um processo orgânico de filmagem e de montagem, bem de acordo com a pedagogia da escola, que alguns qualificam de "orgânica". A música é presença constante no dia-adia da escola. Segundo Therezita, "a música é o primeiro elemento do ser humano para que ele se conheça, conheça seu ritmo interno e o espaço que essa música deve ocupar". Ela acontece durante o tempo todo, instrumentos de todo tipo estão à disposição das crianças. Tanto pode ser uma roda de bumba meu boi, um violinista que chega tocando um trecho de Mozart, um coro de tambores do Maranhão ou um sanfoneiro nordestino. O tempo do filme que alguns acham longo, também reflete o tempo da infância, que é um tempo estendido, um tempo outro, um tempo do imaginário. A interação entre forma e conteúdo, o uso da imagem-câmera conceituada por Fernão Pessoa Ramos fazem de Sementes do nosso quintal uma obra documental que transmite a força de uma pedagogia.

Volta-se à questão do registro do real. Fernão Ramos (2012, p. 14) conceitua as imagens-câmera como imagens de origem mecânica e forma especular, que têm a característica de se remeter à circunstância exterior de sua formação. Assim,

[...] a "imagem-câmera" em movimento se constituiu, em sua evolução, como linguagem cinematográfica e forma narrativa, por meio da decomposição da imagem primeva e de seu espaço, articulando-a por fragmentos (planos) dispostos a fim de realçar relações de sentido entre si (RAMOS, 2012, p. 15). 
O documentário acompanha o ritmo das atividades das crianças; a articulação de diversas cenas do brincar chega a causar, em alguns momentos, a impressão de que se está diante de imagens ao vivo. Há um realce da dimensão da presença na circunstância de mundo que cerca a câmera quando da constituição da imagem. Embora aponte para o corte que a constituirá, a imagem-câmera em movimento, possui, em sua qualidade de durar, a promessa de uma continuidade:

Ao montarmos uma imagem em movimento, particularmente uma imagem-câmera em movimento, lidamos com uma sucessão de unidades que, em si, contêm a marca e a extensão do transcorrer através do movimento (mesmo que imperceptível como expressão) (RAMOS, 2012, p. 15).

A sucessão das imagens de Sementes do nosso quintal trazem componentes de propostas pedagógicas. Ao invés de especialistas falarem sobre a pedagogia da Te-Arte, as imagens falam por si. Então, a inovação não está na captação de imagens não convencionais e sim na montagem que tenta seguir uma sequência natural e não roteirizada. $O$ som ambiente contribui para que os espectadores acessem a ecologia daquele espaço. Ramos acentua a importância do som:

Na análise da imagem-câmera em movimento, é imprescindível, nós nos determos em algo que a constitui de maneira intrínseca: o som como fala e ruídos ou, em forma mais particular, música. Na verdade, a designação mais precisa para a imagem que tratamos seria imagem-câmera sonora em movimento, forma que não utilizamos para facilitar a expressão. A fala e os ruídos compõem a imagem e o movimento como um todo, pois é assim que estão presentes nos objetos e nos seres que surgem ao sujeito-dacâmera, deixando seu traço no suporte (RAMOS, 2012, p. 19).

A relação imagem-som é onipresente no Sementes. As imagens foram captadas por um processo que corresponde à designação de Fernão Ramos: imagem-câmera sonora em movimento. 


\section{Complexidades em fluxo}

Se pensamos o cinema como espaço educador, o filme documentário parece apresentar mais condições de trabalhar com processos pedagógicos e cognitivos. Muitos documentários foram realizados para trazer informações históricas, geográficas, sociais, para que mais pessoas conhecessem lugares, culturas, personagens famosos ou pessoas comuns. Mais que os filmes ficcionais, os documentários podem ter um papel modelizador e até mesmo uma função mobilizadora. O registro do real permanece como condicionante de credibilidade.

Os três documentários aqui analisados podem ser submetidos à "mirada complexa" de Josep M. Català, que produziu um imenso tratado sobre as imagens: La imagen compleja: la fenomenologia de las imágenes en la era de la cultura visual (2005). Conservamos o termo mirada em espanhol, devido a uma não correspondência com olhar ou ver, embora alguns autores façam essa diferença. "Mirada complexa" é um procedimento metodológico que pode ser aplicado a diversos objetos, sejam fotografias, vídeos, imagens estáticas ou em movimento, narrativas convencionais ou hipertextuais, narrativas multimidiáticas. Inspirado em Edgar Morin, Català disseca o conceito de complexidade e constrói um novo conceito - imagem complexa - para ser aplicado ao funcionamento das imagens. Aliás, o uso do termo imagem complexa é uma facilitação didática e textual, porque o autor afirma que não se pode falar em imagem isoladamente, mas sempre em imagens, no plural.

Para Català, não se trata de quantificar a quantidade de complexidade que se pode encontrar em uma imagem nem de medir a dilatação das pupilas diante de um quadro famoso. Sua proposta é pensar as imagens, mas também pensar com as imagens: "não só obter conhecimentos por meio das imagens, mas também ser possível refletir visualmente sobre esse saber" (CATALÀ, 2005, p. 22). Ele imagina que: 
Porém, é desta arquitetura, que combina o interno e o externo, o fixo e o móvel, o espaço e o tempo, o subjetivo e o objetivo, onde surge a verdadeira complexidade visual. [...] Tratava-se de pensar as imagens, mas também pensar com as imagens, para pôr de manifesto sua particular fenomenologia $e$ os problemas epistemológicos cognitivos e estéticos que ela traz (CATALÀ, 2005, p. 22).

A complexidade se refere a uma forma de interrogar as imagens. $O$ fenômeno da imagem complexa se move portanto entre uma "mirada complexa" e uma plasmação complexa. Na construção do conceito, ele distingue as imagens da ciência e da objetividade - que podem ser qualificadas como visualidades científicas, documentais ou jornalísticas etc. - das imagens complexas. Há oposições entre as imagens objetivas e as imagens complexas.

A primeira oposição é entre transparência e opacidade. A visualidade científica, relacionada com o mito fundador do conhecimento ilustrado, busca a transparência. É uma imagem que quer reproduzir a superfície do mundo. A imagem complexa é opaca, não é uma janela para o mundo, não é um lugar de trânsito para uma determinada realidade. Ela nos pede uma atitude de deciframento, uma apropriação cognitiva. As imagens de Um homem com uma câmera, Valsa com Bashir e Sementes do nosso quintal apresentam um certo grau de transparência, mas o filme de Vertov tende mais à opacidade e solicita deciframento. Todos pedem uma apropriação cognitiva.

A segunda oposição apontada por Català é mimese $x$ exposição. As visualidades científicas tendem a mimetizar a realidade. A exacerbação do mito da imagem mimética, que seria uma cópia da realidade, leva ao simulacro - imagens que substituem a realidade. Nossa visão, construída culturalmente, apela para a mimese como fator de compreensão das imagens. A mimese é uma das justificativas do fotojornalismo e dos documentários, mesmo com toda a carga de subjetividade e manipulação que uma fotografia ou um filme possam conter. O dispositivo é ignorado; pensa-se que a imagem é um simples reflexo do real. Pelo contrário, a 
exposição da imagem complexa resulta de uma construção visual que propõe pontos de referência com a realidade sem recorrer necessariamente a um fantasmagórico realismo. Um homem com uma câmera e Valsa com Bashir trabalham com uma construção visual inclui pontos de referência com a realidade. Sementes apresenta uma filmagem realista que, no entanto, estimula reflexão sobre formas de documentar um ambiente em que as crianças pequenas são protagonistas, embora não sejam configuradas como personagens de uma narrativa. O roteiro não pretendeu contar uma narrativa.

Em terceiro lugar, temos ilustração $x$ reflexividade. Todas as imagens que não puderam ser relacionadas com as artes tradicionais (pintura, escultura, arquitetura e, posteriormente, fotografia e cinema) sempre foram consideradas ilustrações, isto é, funcionavam como um complemento visual ao texto. Podiam ser a visualização de uma parte do texto ou ainda simplesmente um adorno. A imagem muitas vezes era um simples artifício mnemotécnico, auxiliar da ciência ou da visualização em materiais impressos. A imagem complexa é reflexiva, num processo que pode ser didático e estético e que envolve camadas de compreensão. Ela pode ter uma natureza multimagnética, ou ainda ser uma imagem sintética que se constitua em porta ou interface para outros tempos e espaços. Os três documentários aqui examinados envolvem reflexão e solicitação de compreensão de suas finalidades didáticas e estéticas.

Espetacularidade se contrapõe à interatividade: esta é a quarta oposição. O caráter espetacular das imagens contemporâneas solicita uma fruição passiva, enquanto que a interatividade possibilita ações do espectador. Rememorando Guy Debord e a sociedade do espetáculo, Català (2005, p. 81) nos diz que praticamente todas as imagens modernas estão construídas para serem observadas à distância por um observador colocado em uma situação privilegiada que se sente controlando o que vê. Porém, ele não tem controle e quase sempre é envolvido pelo aparente realismo 
proposto por essas imagens. A imagem interativa é aquela que permite que o espectador se transforme em agente. Para o processo de interação, a interface é um fator básico. Embora os três documentários não envolvam interatividade, seus espectadores estão sendo tratados como receptores ativos.

A imagem científica e objetiva supõe o conceito tradicional de imagem transparente, mimética, ilustrativa e espectatorial; substitui a razão pela persuasão. Em contraposição, a imagem complexa é opaca, expositiva, reflexiva e interativa, porque, contaminando-se pela arte, pela subjetividade e pelas emoções, dá lugar a uma nova objetividade, a uma visualidade que Català chama de pós-científica. O autor pondera que a história da imagem é muito variada e que nem todas as imagens que precederam a interface têm essas características e nem sempre funcionam nesse sentido pejorativo. Além disso, a complexidade é também um processo hermenêutico que pode aplicar-se ao mais simples dos fenômenos para redimi-lo do seu reducionismo.

\section{Pensar as imagens, pensar com imagens}

Há muitos anos, os estudos visuais fornecem matrizes importantes para nossas pesquisas. A formação de imagens referenciais, estáticas ou em movimento, para finalidades jornalísticas ou documentais é ponto central de reflexão, análise e proposta de novas aplicações. Neste trabalho, a preocupação se dirigiu para a imagética de documentários cinematográficos. Após considerações sobre a representação do real operada por documentários, foram selecionados três filmes que trouxeram inovações no discurso visual, provocando questionamentos e estimulando possibilidades criativas para produções futuras.

Trabalhamos com os conceitos de fotografia-documento, fotografiaexpressão, imagem-câmera, imagem complexa, para analisar documentários que construíram novas miradas para representar o mundo; 
todos têm uma dimensão experimental. Os documentários Um homem com uma câmera (1929), Valsa com Bashir (2008) e Sementes do nosso quintal (2012) caminharam da imagem-documento para a imagem-expressão, sem no entanto se separarem do real. Eles nos trazem conhecimento por seus conteúdos e pelas formas de suas visualidades. Também possibilitaram que conceitos de diferentes autores interagissem entre si. Assim, fotografiaexpressão de Rouillé, ao chamar a atenção para suas formas visuais e sua escrita, para a subjetividade do autor e para a presença do Outro, conversa diretamente com a imagem complexa de Català, que também implica em considerar a presença de imagens expressivas por influência de subjetividade, de arte e de emoção. Esses filmes não trazem imagens meramente transparentes; as doses de opacidade provocam estranhamento e às vezes proximidade. Não são miméticos; procuram expor e sugerir outras visões. Não ilustram; provocam reflexão. Não se dirigem a espectadores passivos; pedem reação.

Um homem com uma câmera realizou a ideia transgressora de Vertov de romper com a narrativa da literatura e a dramatização do teatro. Sua proposta de perseguir uma linguagem cinematográfica original, com sua articulação entre formas dos objetos e comparação entre movimentos, conseguiu produzir imagens-expressão, que podemos classificar como imagens complexas. Mesmo com toda a revolução tecnológica, Um homem com uma câmera ainda serve de inspiração para edição de imagens. Lev Manovich, em seu livro The Language of New Media, constrói um prólogo em que utiliza uma sequência de fotogramas do filme de Vertov, acompanhada de textos que funcionam como uma espécie de trailer do que será lido. Trata-se de um prólogo visual para uma obra teórica. Valsa com Bashir utiliza a narrativa, mas suas imagens, que não são documento, que não têm transparência, mesmo assim se referem a um contexto documental. Ao mesmo tempo, se movimentam em águas profundamente artísticas. Sementes do nosso quintal não apresenta imagens anticonvencionais; porém sua construção baseada em sequência de cenas, 
sem que haja interrupção por depoimentos de participantes ou especialistas, em uma estética de imagem-câmera, altera o discurso documental e guarda uma sintonia com a proposta pedagógica que está sendo registrada. Desse modo, Sementes dissemina imagens-expressão e imagens complexas.

Os três filmes trazem informação, conhecimento, formação. Os três filmes trazem engenho e arte. Propõem exercícios de pensamento e formas de criação. Eles nos fazem pensar sobre o conteúdo e nos fazem pensar sobre as imagens que nos apresentaram esse conteúdo. Mais ainda, as imagens desses filmes permitem que pensemos com imagens. São imagens pensativas, que provocam reflexão sobre como produzir imagens mais significativas sobre o mundo. São imagens-fluxo de pensamento. 


\section{Referências}

CATALÀ DOMĖNECH, Josep M. Viaje al centro de las imágenes. Santander: Shangrila, 2017.

CATALÀ, Josep M. La imagen compleja: la fenomenologia de las imágenes en la era de la cultura visual. Bellatera: Universitat Autònoma de Barcelona. Servei de Publicacions, 2005.

DUBOIS, Philippe. Cinema, vídeo, Godard. São Paulo: Cosac Naify, 2004.

DUBOIS, Philippe. O ato fotográfico. Campinas: Papirus, 1994.

FIGUEIREDO, Fernanda Heinz. Sementes do nosso quintal. Documentário. Brasil, 2012. $118 \mathrm{~min}$. Trailer oficial disponível em: < https://www.youtube.com/watch?v=S1-6qjsw9OI >.

FOLMAN, Ari. Valsa com Bashir. Filme de animação. Israel, Austrália, Bélgica, Finlândia, França, Alemanha, Suíça, Estados Unidos, 2008. 90 min. Disponível em: < https://www.youtube.com/watch?v=5BHmANfNUYQ\&t=1357s >.

LEDO, Margarita. Documentalismo fotográfico. Madrid: Cátedra, 1998. MANOVICH, Lev. The language of new media. Cambridge: MIT Press, 2001. MORIN, Edgar. Cultura de massas no século XX. Rio de Janeiro: Forense, 1969.

OMAR, Arthur. Congo. Brasil, 1972. Disponível em: < https://www. youtube.com/watch?v=DP5303gnSOM >.

OMAR, Arthur. O antidocumentário provisoriamente. Revista de Cultura Vozes, n. 6, ano 72, p. 405-418, 1978.

RAMOS, Fernão Pessoa. A imagem-câmera. Campinas, SP: Papirus, 2012.

ROUILLÉ, André. A fotografia: entre documentos e arte contemporânea. São Paulo: Senac, 2009.

SINOPSE e material de suporte do documentário Sementes do nosso quintal. Acesso em: 14 maio 2018. Disponível em: < https://videocamp-produs.s3.amazonaws.com/uploads/movie_exhibition/support_material_pt/000/000/ 130/130/Sementes_press.pdf >. Acesso em: 23 mar. 2017.

VERTOV, Dziga. Extrato do ABC dos kinoks (1929). In: XAVIER, Ismail. A experiência do cinema. Rio de Janeiro: Graal, 1983a.

VERTOV, Dziga. Nascimento do Cine-olho (1924). In: XAVIER, Ismail. A experiência do cinema. Rio de Janeiro: Graal, 1983b.

VERTOV, Dziga. Nós - variação do manifesto (1922). In: XAVIER, Ismail. A experiência do cinema. Rio de Janeiro: Graal, 1983c.

VERTOV, Dziga. Resolução do conselho dos três (1923). In: XAVIER, Ismail. A experiência do cinema. Rio de Janeiro: Graal, 1983d.

VERTOV, Dziga. Um homem com uma câmera. Rússia, 1929. Disponível em: <https://www.youtube.com/watch?v=QZoddf7_GmQ>. 